\title{
SISTEM COMPLAINT HANDLING BERBASIS ISO 10002:2004 PADA FAKULTAS ILMU KOMPUTER UNIVERSITAS BANDAR LAMPUNG UNTUK MENINGKATKAN RESPONSIBILITAS PENANGANAN KELUHAN
}

\author{
Arnes Yuli Vandika \\ Program Studi Teknik Informatika \\ Fakultas Ilmu Komputer \\ Universitas Bandar Lampung \\ Jln. Z.A. Pagar Alam No.26 Labuhan Ratu Bandar Lampung 35142 \\ Telp. (0721) 701463, (0721) 701979 Fax. (0721) 701467 Web. www.ubl.ac.id
}

\begin{abstract}
Abstrak
Teknologi informasi dan komunikasi telah menyetuh berbagai kegiatan dalam kehidupan manusia, salah satunya pada penanganan keluhan (handling complaint) yang dibutuhkan oleh setiap perusahan. Dan untuk mempermudah proses pengaduan dibutuhkan suatu sistem handling complaint yang berbasis ISO 10002 : 2004, yang diambil dari data kemampuan, pengetahuan dan sistemnya berjalan secara automatis Salah satu yang menjadi acuan bagi penangan keluhan untuk kepuasan pelanggan adalah ISO 10002 : 2004 karena disana terdiri dari berbagai klausal yang berkaitan dengan penangan keluhan,(Marimin, 1992), dalam membangun sistem handling complaint diperlukan suatu langkah yang strategis dan sistematis dimana sistem handling complaint diterapkan di Fakultas Ilmu Komputer Universitas Bandar Lampung.
\end{abstract}

Kata kunci : Handling Complaint, ISO 10002 : 2004

\section{PENDAHULUAN}

Sistem penanganan keluhan pelanggan korporat yang sebagian masih manual menyebabkan timbulnya delay waktu dalam proses penyampaian keluhan dari front liner kepada backroom, hal ini menyebabkan bertambah lamanya waktu yang dibutuhkan untuk menyelesaikan keluhan, yang juga berakibat pada menurunnya kepercayaan pelanggan pada perusahaan (Chrisantiana, 2007) .

Untuk mempermudah proses pengaduan dibutuhkan suatu sistem handling complaint yang berbasis ISO 10002 : 2004, yang diambil dari data kemampuan, pengetahuan dan sistemnya berjalan secara automatis. Dalam membangun sistem handling complaint diperlukan suatu langkah yang strategis dan sistematis dimana sistem handling complaint diterapkan, karena sistem handling complaint harus dilengkapi dengan syarat, tampilan sistem yang mudah dipahami (user interface), serta mempunyai service quality yang baik (Davidoff, 1994).
Dari sistem handling complaint yang berbasis ISO 10002 : 2004 maka di perlukan data masukan dari user dan ahli yang berdasarkan permasalahan dan solusi yang ditampung menjadi knowledge-based yang nantinya akan dimanfaatkan menjadi solusi permasalahan yang di hadapi oleh pengguna sistem handling complaint.

Salah satu yang menjadi acuan bagi penangan keluhan untuk kepuasan pelanggan adalah ISO 10002 : 2004 karena disana terdiri dari berbagai klausal yang berkaitan dengan penangan keluhan,(Marimin, 1992), dalam membangun sistem handling complaint diperlukan suatu langkah yang strategis dan sistematis dimana sistem handling complaint diterapkan di Fakultas Ilmu Komputer Universitas Bandar Lampung.

\subsection{Identifikasi Masalah}

Berdasarkan latar belakang diatas dapat disimpulakan permasalahan, yaitu : 
1. Bagaimana membentuk sistem pengaduan yang bisa dengan cepat berjalan otomatis.

2. Proses penyampaian keluhan yang masih manual dalam bentuk form yang menyebabkan timbulnya delay waktu dalam proses penyampaian keluhan.

3. Bagaimana menerapkan ISO $10002: 2004$ pada handling complaint pada Fakultas Ilmu Komputer Universitas Bandar Lampung.

\subsection{Batasan Masalah}

Agar pembahsan penelitian ini tidak menyimpang dari apa yang telah dirumuskan, maka diperlukan batasan-batasan. Batasanbatasan dalam penelitian ini adalah merancang dan membuat interface berbasis web untuk mengakses data keluhan dari sistem handling complaint pada Fakultas Ilmu Komputer Universitas Bandar Lampung.

\subsection{Rumusan Masalah}

Bedasarkan latar belakang diatas dapat diuraikan rumusan masalahnya, yaitu:

1. Bagaimana membuat sistem handling complaint pada Fakultas Ilmu Kompter Universitas Bandar Lampung yang bisa menyelesaikan penanganan keluhan secara cepat dan berjalan secara otomatis?

2. Bagaimana membangun desain perancangan sistem handling complaint pada Fakultas Ilmu Komputer Universitas Bandar Lampung?

\subsection{Tujuan Penelitian}

Adapun tujuan penelitian ini adalah sebagai berikut :

1. Membuat suatu sistem handling complaint, dalam proses penyelesaian pengaduan berjalan secara cepat dan otomatis.

2. Memberikan laporan yang akurat dan sesuai kebutuhan yang diperlukan

\subsection{Manfaat Penelitian}

Adapun manfaat dari penelitian ini yaitu :

1. Dapat membantu sebagai bahan pertimbangan dalam menentukan handling complaint.
2. Manfaat teoritis dari penelitian ini adalah untuk memberi sumbangan pemikiran bagi perkembangan Pendidikan Ilmu Komputer dan dapat digunakan untuk pengembangan penelitian-penelitian lebih lanjut.

3. Manfaat praktis yaitu menghasilkan produk berupa suatu aplikasi untuk mendeteksi.

\section{LANDASAN TEORI}

\subsection{Handling Complaint (Penanganan Keluhan)}

Keluhan diartikan sebagai sesuatu yang tidak menyenangkan atau sesuatu yang mengganggu. Chartered management Istitute, mendefinisikan keluhan sebagai suatu ungkapan kurang puas akan produk atau pelayanan baik lisan maupun tulisan dari pelanggan internal dan ekseternal (LAN, 2005). Lebih lanjut, keluhan diartikan sebagai penyataan ketidak puasan, apapun bentuknya (tertulis maupun lisan) tentang pelayanan tindakan atau kekurangan yang dilakukan oleh instansi penyedia pelayanan atau para stafnya yang memepengaruhi atau dirasakan oleh para pengguna pelayanan tersebut (LAN,2006).

Organisasi pelayanan tidak responsif terhadap kebutuhan dan keinginan serta harapan pelanggan Menurut Endar Sugiarto (1999), keluhan pelanggan dapat dikategorikan/dikelempokkan menjadi empat, yaitu :

a) Mechanical Complaint (keluhan mekanical) adalah suatu keluhan yang disampaikan oleh pelanggan sehubungan dengan tidak berfungsinya peralatan yang dibeli/disampaikan kepada pelanggan tersebut. Atau dengan kata lain, produk/output dari pelayanan yang diberikan tidak sesuai dengan yang diharapkan. Hal ini dapat terjadi karena kerusakan atau kualitas tidak maksimal.

b) Attitudinal Complaint (Keluhan akibat sikap petugas pelayanan) adalah keluhan pelanggan yang timbul karena sikap negative petugas pelayanan pada saat melayani pelanggan. Hal ini dapat dirasakan oleh pelanggan melalui sikap tidak peduli dari petugas pelayanan terhadap pelanggan.

c) Service Related Complaint (Keluhan yang berhubungan dengan pelayanan) adalah suatu 
keluhan pelanggan karena hal-hal yang berhubungan dengan pelayanan itu sendiri. Misalnya seseorang mendaftar untuk ikut suatu diklat, ternyata formulir pendaftaran belum siap dan oleh petugas diminta untuk menunggu.

d) Unusual Complaint (Keluhan yang Aneh) adalah keluhan pelanggan yang bagi petugas merupakan keanehan (tidak wajar/tidak umum). Pelanggan yang mengeluh seperti ini.

\subsubsection{Manfaat Handling Complaint (Penanganan Keluhan)}

Martin (1994) menyatakan bahwa : "Mature organizations encourage customers to complaint. They seek to convert complaining customers into satisfied customers." (Organisasi yang mapan mendorong pelanggannya untuk menyampaikan keluhan. Mereka berupaya mengubah pelanggan yang mengeluh menjadi pelanggan yang puas).

Walker (1997) menyatakan keluhan memeberikan sejumlah kesempatan untuk :

1. Mengidentifikasikan kelemahan

2. Membenahi banyak hal

3. Menyelamatkan seorang pelanggan

4. Mendorong loyalitas.

\subsubsection{Elemen-Elemen Handling Complaint}

Penanganan pengaduan pada dasarnya adalah kegiatan penyaluran pengaduan, pemrosesan respons atas pengaduan tersebut, umpan balik, dan laporan penanganan pengaduan. Rangkaian kegiatan ini memiliki elemen-elemen berikut:

1. Sumber atau Asal Pengaduan

Adalah masyarakat, baik secara individu maupun kelompok, dari mana komplain atau pengaduan berasal. Sumber pengaduan terbagi atas jalur internal dan jalur eksternal. Pengaduan dari internal disuarakan oleh masyarakat pemakai langsung kepada penyedia jasa atau layanan sedangkan pengaduan eksternal disuarakan oleh bukan pemakai langsung jasa atau layanan melainkan oleh pihak luar yang menjadi wadah atau saluran pengaduan seperti LSM, Media Elektronik dan Cetak, NGO dan lainlain.

2. Isi Pengaduan

Adalah permasalahan yang diadukan oleh pihak pengadu. Khusus mengenai isi komplain yang berkaitan dengan kinerja dan prilaku staf, maka nama staf yang terkena komplain wajib dirahasiakan sampai komplain telah tertangani secara tuntas.

3. Unit Penanganan Pengaduan

Adalah satuan yang disediakan untuk mengelola dan menanngani pengaduan darimana pun berasal dan melalui saluran manapun. Hasil dari olahan unit ini adalah responds pengaduan.

4. Respond Pengaduan

Adalah responds yang dihasilkan oleh unit penanganan pengaduan dalam organisasi yang terkait dengan pengaduan. Respond ini kemudian disampaikan kepada pihak pengadu.

5. Umpan Balik

Adalah penilaian pihak pengadu atas responds atau jawaban mengenai permasalahan yang mereka ajukan.

6. Laporan Penanganan Pengaduan

Sesudah umpan balik dari pilihan yang mengajukan komplain diterima, maka unit pengelolaan pengaduan wajib membuat laporan tentang pengaduan dan penanganan pengaduan tersebut, termasuk umpan balik dari pihak yang mengadu.

\subsubsection{Mekanisme Penanganan Keluhan}

Mekanisme pengaduan keluhan merupakan mekanisme yang dapat ditempuh oleh pelanggan untuk menyatakan ketidakpuasannya terhadap pelayanan yang diterima. Walker (1997) menyatakan sistem yang mungkin dijalankan untuk penanganan keluhan adalah sebagai berikut

1. Catatlah keluhan (sebaiknya diatas formulir). Catatan ini berisi :

- Siapa yang menerimanya

- Bagaimana keluhan diterima (lewat telpon, surat, langsung, dll)

- Tanggal/waktu keluhan (supaya anda bisa memenuhi standar untuk kerja yang sudah dinyatakan.

- Tindakan 'perbaikan' sementara apa saja yang diperlukan.

2. Beri tahu pelanggan yang berurusan dengan anda dalam hal keluhan, skala waktu dan tindakan seketika yang bisa diambil.

3. Kalau anda bukan orang yang bisa memecahkan masalah, kirimkan copy perincian kepada orang yang bisa melakukannya. 
4. Catatlah tindakan apa saja yang diambil pada waktu keluhandisampaikan untuk berusaha memecahkan masalah.

5. Begitu masalah dipecahkan selesaikan catatan tentang tindakan yang diambil.

6. Tulis surat atau bicaralah dengan pelanggan untuk memberitahu mereka tentang tindakan yang sudah diambil.

- Untuk memecahkan masalah.

- Untuk mengatasi penyebab yang mendorong timbulnya masalah mereka.

- Untuk memberikan ganti rugi.

7. Kirimkan kepada orang yang menerima keluhan satu copy formulir yang menunjukkan tindakan yang telah diambil, dan kalau perlu satu copy surat kepada pelanggan.

8. Pastikan keluhan telah dianalisis dan dimasukkan kedalam data sistem data sentral. Tidak peduli sekecil apapun organisasinya, menyimpan catatan keluhan ada menfaatnya sehingga kecenderungan bisa diidentifikasi.

\subsubsection{ISO 10002 : 2004}

Dalam sebuah organisasi yang akan mengimplementasikan standar ISO 10002:2004 mengenai Sistem penanganan keluhan, mempunyai dua tujuan utama yaitu dapat menangani keluhan dengan baik sehingga hal tersebut memberikan kepuasan baik secara internal maupun eksternal, keluhan yang ditangani dapat menjadikan peningkatan kinerja sebuah pelayanan, indikator dari sebuah kepedulian dan kepuasan pelanggan adalah dengan memberikan complaint atau keluhan. Dalam Standard ISO 10002 : 2004 terdapat model dalam penanganan sebuah keluhan seperti dijelaskan dibawah ini.

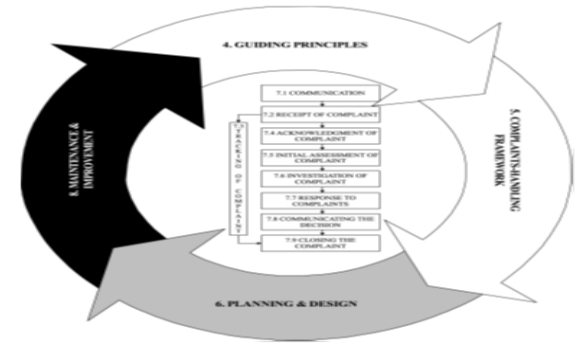

bagian tersebut dalam model yaitu:

Keempat

1. Guiding Principles

2. Complaints Handling Framwork

3. Planning \& Design

\section{Maintenance \& Improvement}

Keempat bagian tersebut mendefinisikan prinsip untuk membantu organisasi dan menjamin sistem penanganan keluhan dapat berjalan secara efektif.

\subsubsection{Kerangka Pemikiran}

Penelitian ini di awali dengan seringnya permasalahan teknologi informasi (TI) yang tidak terselesaikan dengan baik dan tidak meninggalkan jejak rekam dalam penyelesainnya masalah yang ada, sehingga sering terjadi penyelesaian masalah yang tidak sempurna, mulai dari sumber daya manusia (SDM) yang masih kurang dan adapaun delay waktu proses penyampaian keluahan dari front liner kepada backroom, hal ini menyebabkan bertambah lamanya waktu yang dibutuhkan untuk menyelesaikan keluhan, yang juga berakibat pada menurunnya kepercayaan pelangan.lambatnya penyelesaian pengaduan pemecahan masalah TI, maka dari hasil pengamatan perlu di buatkan suatu sistem yang bisa membantu user yang menggunakan suatu handling complaint sistem bisa mengetahui permasalahan yang di hadapi dan proses pemecahan masalah yang di hadapi bisa di ketahui, sehingga menambah knowledge baru dalam bidang TI, dan berikut kerangka pemikiran seperti gambar di bawah ini.

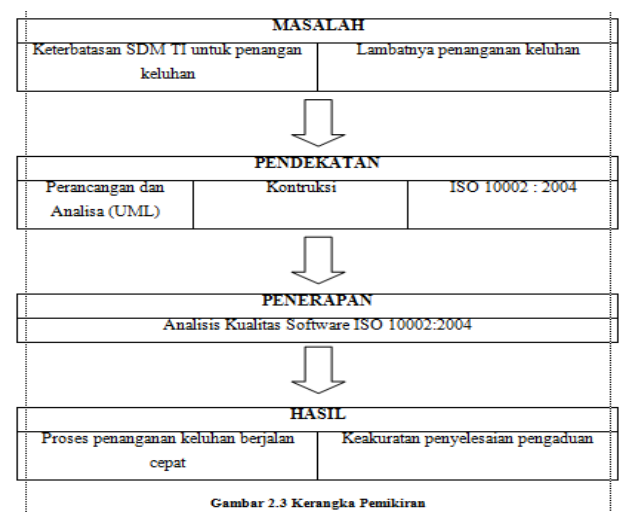

Dari gambar diatas bisa di simpulkan bahwa handling complaint sistem berbasis ISO 10002 : 2004 mampu mengatasi permasalahan yang disebabkan karena masih manualnya sistem yang ada hingga menimbulkan delay waktu dalam proses penyampaian keluhan, dengan adanya sistem ini penanganan keluhan tidak harus diselesaikan secara konfensional baik proses penerimaan pengaduan hingga proses penyelesaian permasalahan dengan cepat, tetapi 
bisa di bantu dengan sistem ini dalam proses penyelesaian permasalahan, yang berguna untuk permasalahan yang sama atau di jadikan sebagai bahan referensi knowledge untuk permasalahn yang hampir sama.

\section{Perancangan dan Implementasi}

\section{1 metodologi analisis}

Peneliti menggunakan metodologi analisis dengan tujuan untuk membantu menganalisa sistem yang sedang berjalan di fik ubl:

\section{a. Functional decomposition methodologies}

Metodologi pengembangan sistem ini dengan memecahkan sitem menjadi subsistemsubsistem yang lebih kecil, sehingga mudah dipahami, dirancang dan diterapkan.

\section{b. Data-flow oriented methodologies}

Metodologi ini secara umum didasarkan pada pemecahan dari sistem kedalam modul-modul berdasarkan dari tipe elemen data dan tingkah laku logika modul tersebut didalam sistem. Dengan metodologi ini, sistem secara logika dapat digambarkan secara logika dari arus data dan hubungan antar fungsinya didalam modul-modul sistem.

\section{c. Black Box (Kotak Hitam)}

Strategi dasar blackbox testing terletak pada pemilihan data yang sesuai dengan fungsinya. Dalam rangka melaksanakan strategi blackbox testing, penguji harus tahu bagaimana sistem harus berprilaku sebagai respon terhadap tindakan tertentu. Blackbox testing kadang juga disebut sebagai "Opaque Testing" , seperti namanya blackbox testing menunjukkan tidak ada pengetahuan tentang logika internal atau struktur kode diperlukan.

\section{d. White Box (Kotak Putih)}

Strategi white box berkaitan dengan logika internal dan struktur kode. Pengujian harus berurusan dengan kode dan karena itu diperlukan untuk memiliki pengetahuan tentang koding dan logika kerja internal yaitu kode.

\subsection{Perancangan Penelitian}

\subsubsection{Variabel Penelitian}

Pada penelitian ini akan di lakukan dengan penyebaran kuesioner dengan sampel berjumlah 6 orang. Kuesioner ini akan meneliti karateristik Visibility, Accessibility, Responsiveness, Objectivity, Confidentiality, dan customer focused approach dari website Fik Complaint yang nantinya seperti pada Tabel 3.2. Keterangan Kuesioner Penelitian Website Fik Complaint.

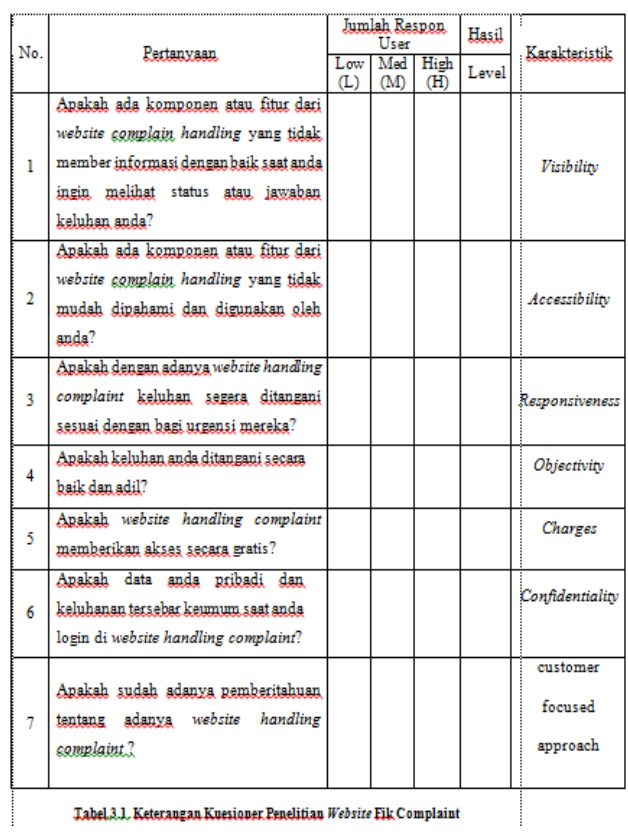

Tabel diatas adalah tabel kuisoner penelitian website FIK Complaint, tabel tersebut berisi pertanyaan dan karakteristik-karakteristik ISO 10002 : 2004, quisoner ini diberikan pada mahasiswa tentunya yang sudah menggunakan website Fik Complaint. Jumlah respon diatas menerangkan jika :

a. High adalah jika jumlah responden menghasilkan high maka responden menunjukan seberapa besar minat responden terhadap website Fik Complaint dan menunjukan bahwa responden memberikan respon yang baik terhadap website Fik Complaint.

b. Medium adalah jika jumlah responden menghasilkan Medium maka responden menunjukan seberapa besar minat responden terhadap website Fik Complaint dan menunjukan bahwa responden memberikan respon yang 
lumanyan baik atau sedang terhadap website Fik Complaint.

c. Low adalah jika jumlah responden menghasilkan Low maka responden menunjukan seberapa besar minat responden terhadap website Fik Complaint dan menunjukan bahwa responden memberikan respon yang tidak baik terhadap website Fik Complaint.

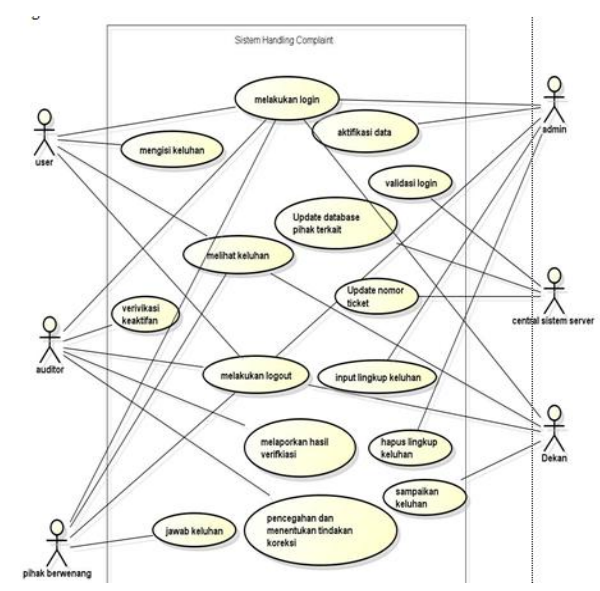

\section{Gambar 3.2 Use case diagram handling complaint system}

\subsection{IMPLEMENTASI}

Apabila hasil pengujian dan testing telah di lakukan dengan baik maka sistem tiket pengaduan berbasis ISO 10002 : 2004 telah siap untuk di gunakan dan siap di implementasikan pada user yang berkepentingan dengan modul sistem,sehingga kebutuhan user akan modul sistem akan terpenuhi dengan baik, adapun sasaran dari system handling complaint pengaduan berbasis ISO 10002 : 2004 adalah user tiap divisi dan divisi IT yang berkepetingan akan sistem tersebut dalam suatu organisasi perusahaan.

\subsubsection{Interface Pengguna}

Berikut adalah beberapa tampilan antar pengguna untuk berinteraksi dengan sistem.

1. Form home

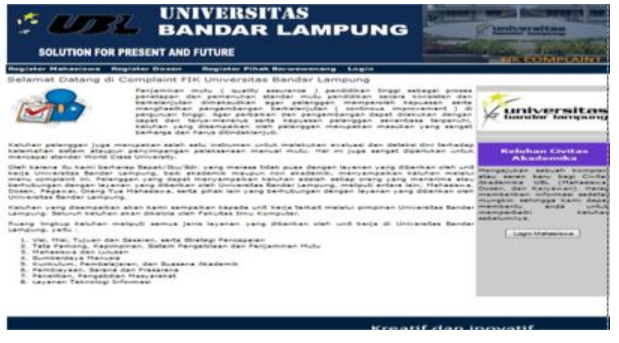

Gambar 4.8 Form Home

2. Form register Mahasiswa

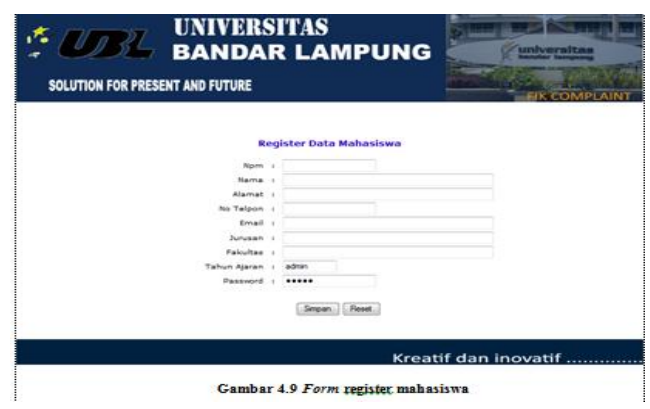

Form ini bisa digunakan untuk register mahasiswa pada mahasiswa yang belum pernah melakukan Register sebelumnya. Mahasiswa diwajibkan untuk mengisi form ini karna data tersebut yang nantinya akan mendapat akses login, data tersebut harus valid karna data tersebut yang nantinya akan diperiksa oleh admin jika data tersebut valid maka mahasiswa tersebut baru dapat diberi akses login jika tidak sebaliknya.

\section{Form register Dosen}

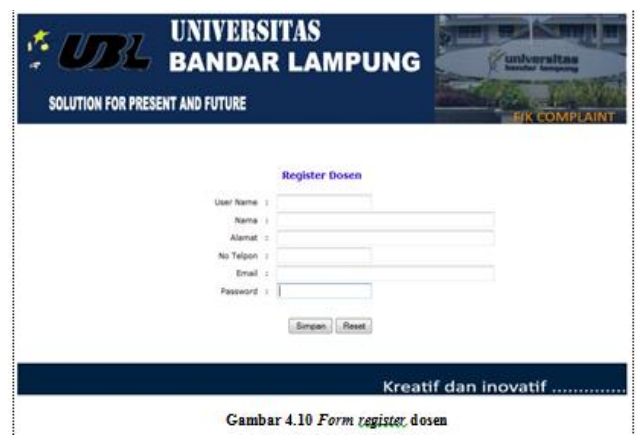

Form ini bisa digunakan untuk register dosen pada dosen yang belum pernah melakukan register sebelumnya. dosen diwajibkan untuk mengisi form ini karna data tersebut yang nantinya akan mendapat akses login, data tersebut harus valid karna data tersebut yang nantinya akan diperiksa oleh admin jika data tersebut valid maka dosen tersebut baru dapat diberi akses login jika tidak sebaliknya. 
4. Form register pihak berwenang

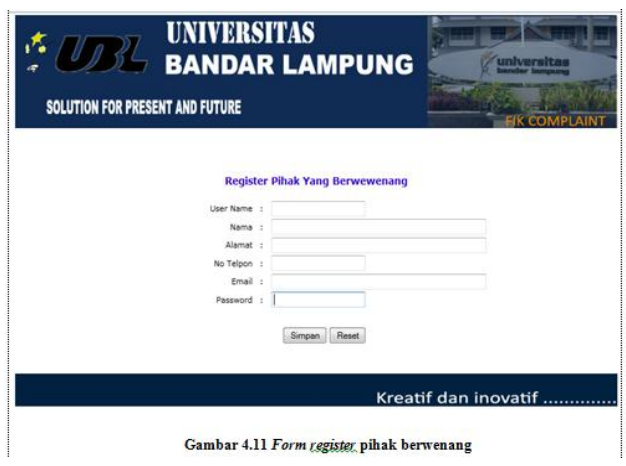

Form ini bisa digunakan untuk register pihak berwenang pada pihak berwenang yang belum pernah melakukan register sebelumnya. Mahasiswa diwajibkan untuk mengisi form ini karna data tersebut yang nantinya akan mendapat akses login, data tersebut harus valid karna data tersebut yang nantinya akan diperiksa oleh admin jika data tersebut valid maka mahasiswa tersebut baru dapat diberi akses login jika tidak sebaliknya.

\section{Form menu mahasiswa}

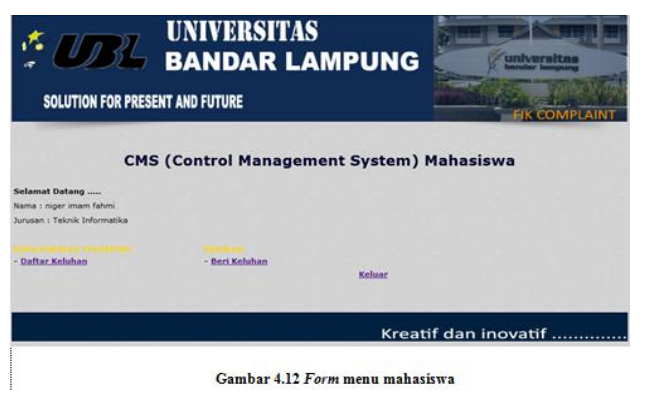

Form ini adalah menu mahasiswa, di form ini terdapat nama dan $\mathrm{npm}$ anda seperti contoh gambar diatas. Mahasiswa dapat melihat keluhan dan memlihat keluhan tetapi mahasiswa tersebut harus login terlebih dahulu sebelumnya. Di form ini terdapat link keluar link tersebut berfungsi untuk keluar dari situs tersebut.

\section{Form Keluhan}

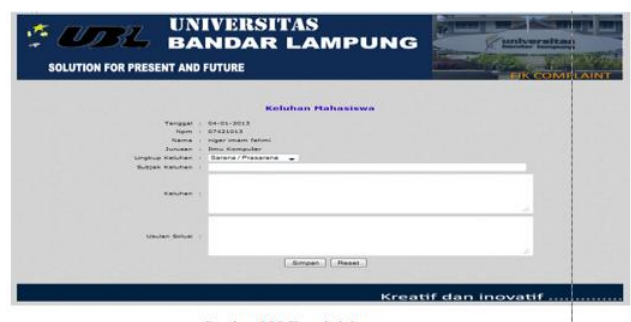

Form ini form mahasiswa yang sebelumnya login dan masuk ke form menu mahasiswa memilih link beri keluhan, form ini berfungsi untuk memberi keluhan yang nantinya akan disampaikan secara otomatis ke Dekan Fik UBL dan akan segera diproses.

\section{Form Menu Admin}

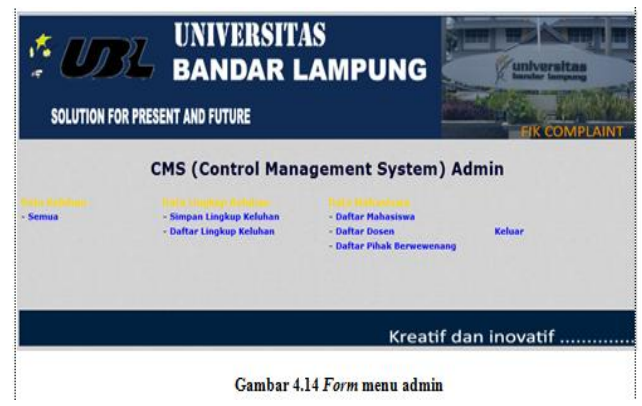

Form ini admin bisa mengelolah daftar keluhan, lingkup keluhan, dan juga memberikan akses login pada user yang ingin memberikan keluhan tapi sebelumnya dia harus melakukan registrasi terlebih dahulu.

\section{Form Admin aktifasi}

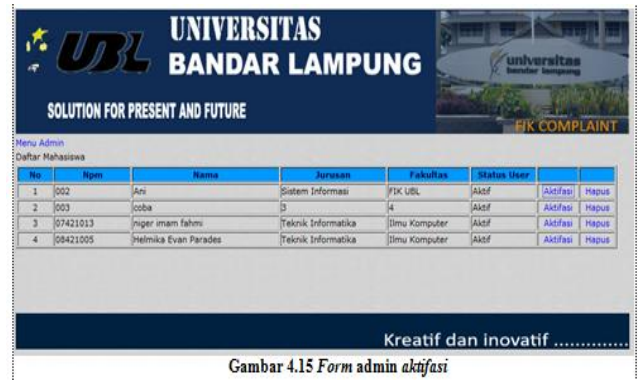

Form ini adalah form admin di form ini terdapat daftar mahasiswa yang terlah melakukan registrasi untuk memberika akses login admin harus mencocokan data dengan data yang ada, jika data tersebut sesuai dengan data yang admin punya maka admin harus memberi akses login dengan mengklik aktifasi.

\section{Form Daftar keluhan Admin}




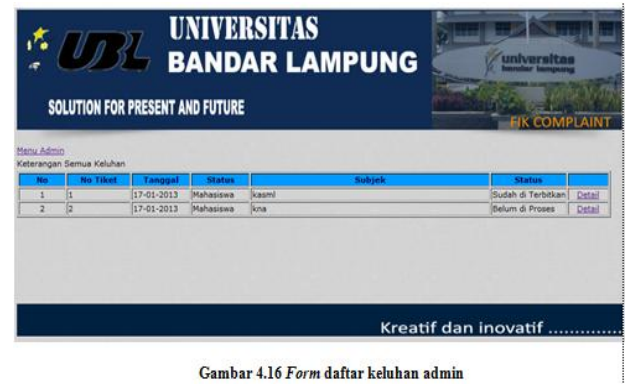

Form ini berisikan semua daftar keluhan mahasiswa, form ini hanya dapat di akses oleh admin. Admin di form ini hanya dapat melihat tangal, status, subjek dan status keluhan tersebut karna harus menjaga kerasian data bagi user yang telah memberikan komplain kepada Fik UBL.

\section{Form Simpan Lingkup Keluhan}

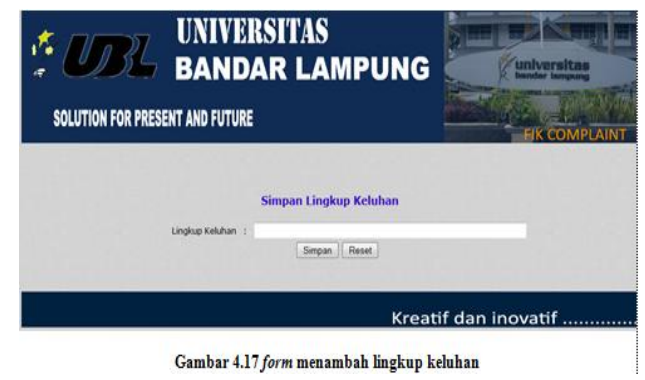

Dalam menu admin terdapat menu simpan lingkup keluhan yang berfungsi untuk menambahkan lingkup keluhan jika ada penambahan dalam lingkup keluhan.

\section{Form daftar Lingkup Keluhan}

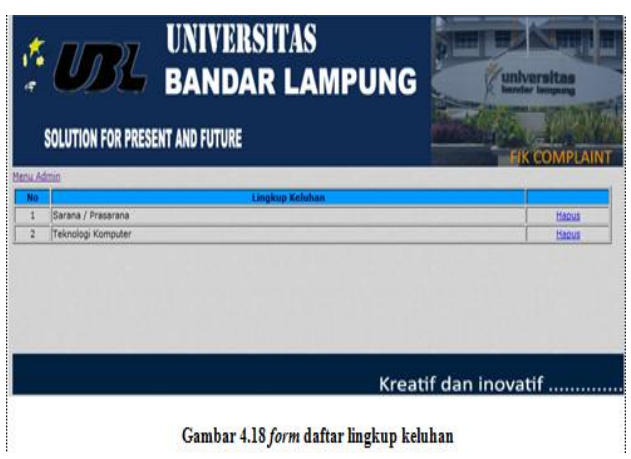

Di form ini berisikan daftar lingkup keluhan yang terlebih dahulu sudah tersimpan dan di form ini juga bisa menghapus lingkup keluhan dengan cara pilih lingkup keluhan yang akan dihapus didalam baris lingkup keluhan yang anda pilih ada link hapus, admin harus mengklik tombol hapus jika admin ingin menghapus lingkup keluhan tersebut.
12. Menu pihak berwenang

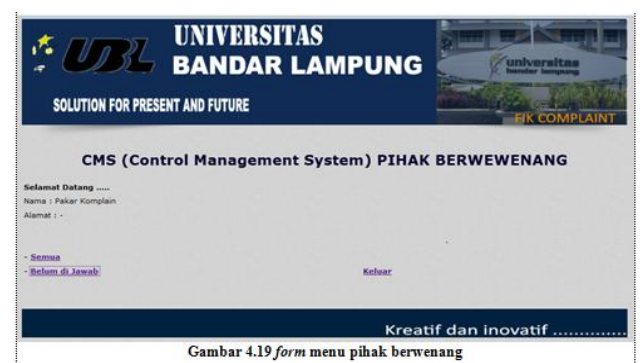

Di form ini pihak berwenang bisa melihat semua daftar keluhan dan bisa juga melihat daftar keluhan yang belum dijawab oleh pihak berwenang tetapi sebelumnya pihak berwenang harus melakukan login terlebih dahulu untuk bisa mengakses form ini. Di form ini terdapat link keluar link tersebut berfungsi untuk keluar dari situs tersebut.

\section{Form jawab keluhan}

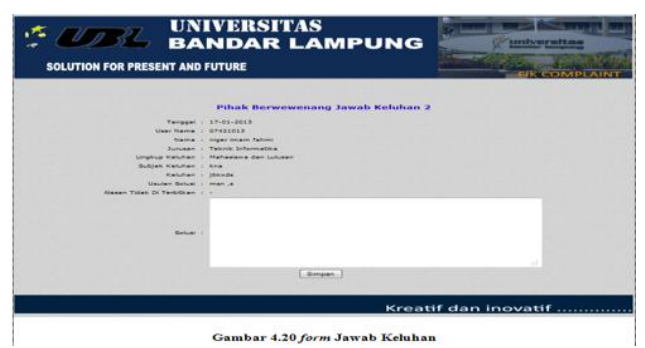

Di form ini pihak berwenang dapat menjawab sebuah keluhan yang sebelumnya telah diberi tugas oleh dekan untuk menyelesaikan keluhan tersebut, jika pihak berwenang sudah menjawab keluhan tersebut maka pihak berwenang harus menekan tombol simpan.

14. Form menu dekan

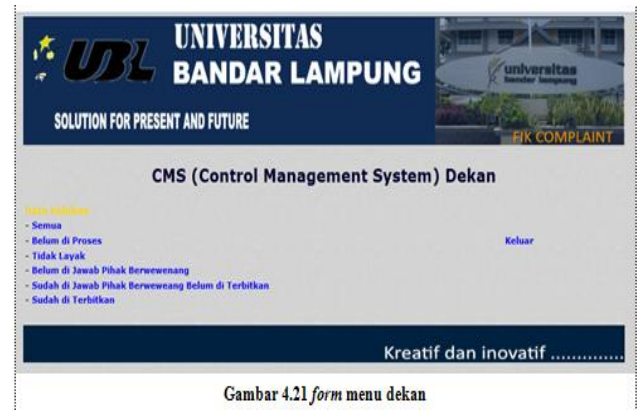

Form ini menampilkan menu yang hanya dapat digunakan oleh dekan. Dekan mempunyai peranan besar dalam fik complaint, dekan harus melihat isi keluhan dan memberikan tugas kepada pihak berwenang untuk menjawab keluhan 
tersebut. Di form ini terdapat link keluar link tersebut berfungsi untuk keluar dari situs tersebut.

\section{Form semua daftar keluhan}

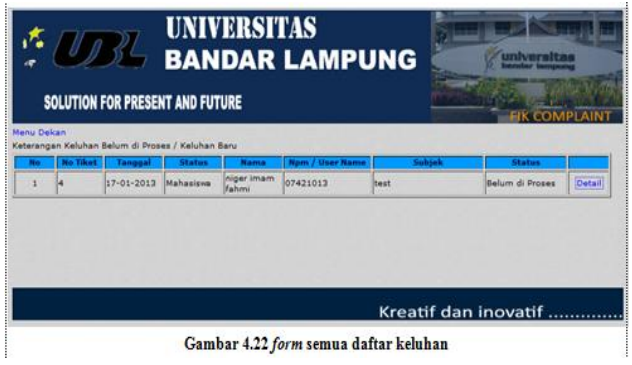

Form ini berisi semua daftar keluhan yang sudah dikirim dari mahasiswa atau dosen. Di form ini dekan bisa melihat keluhan secara detail dengan mengklik detail yang ada di menu dekan.

16. Form proses keluhan

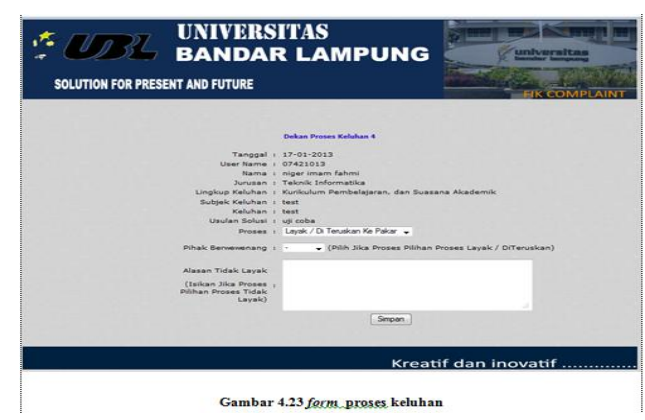

Di form ini terdapat keluhan yang akan diproses untuk diteruskan ke pihak berwenang, tetapi sebelumnya keluhan ini harus ditinjau dahulu apakah keluhan ini layak atau tidak layak untuk di proses.

\section{SIMPULAN DAN SARAN}

\subsection{Simpulan}

Setelah menganalisa hasil kuesioner, hasil tersebut dibandingkan dengan level yang dibutuhkan didalam standar ISO 10002:2004

Tabel 5.1. Hasil Penelitian Website FIK

Complaint berdasarkan ISO 10002:2004

\section{Analisis Kualitas Produk}

\begin{tabular}{|c|c|c|c|}
\hline Karakteristik & $\begin{array}{c}\text { Hasi } \\
\text { I }\end{array}$ & $\begin{array}{c}\text { Level yang } \\
\text { dibutuhka } \\
\text { n }\end{array}$ & $\begin{array}{c}\text { Hasil } \\
\text { Penelitia } \\
\text { n Aktual }\end{array}$ \\
\hline Visibility & $\mathrm{H}$ & $\mathrm{H}$ & Sesuai \\
\hline Accessibility & $\mathrm{H}$ & $\mathrm{H}$ & Sesuai \\
\hline $\begin{array}{c}\text { Responsivenes } \\
\text { s }\end{array}$ & $\mathrm{H}$ & $\mathrm{H}$ & Sesuai \\
\hline $\begin{array}{c}\text { Objectivity } \\
\text { Charges }\end{array}$ & $\mathrm{M}$ & $\mathrm{H}$ & Sesuai \\
\hline $\begin{array}{c}\text { Confidentialit } \\
\mathrm{y}\end{array}$ & $\mathrm{H}$ & $\mathrm{H}$ & Sesuai \\
\hline $\begin{array}{c}\text { customer } \\
\text { focused } \\
\text { approach }\end{array}$ & $\mathrm{M}$ & $\mathrm{M}$ & Sesuai \\
\hline
\end{tabular}

Berdasarkan Penelitian secara keseluruhan menghasilkan beberapa temuan penting yang dapat dirumuskan dalam kesimpulan sebagai berikut:

1. Karateristik Visibility didalam penelitian menghasilkan level High, sedangkan Level yang dibutuhkan adalah High. Sehingga Hasil Penelitian menyatakan website Fik complaint UBLdi karaktersitik Visibility sesuai dengan standar ISO10002:2004.

2. Karateristik Accessibility didalam penelitian menghasilkan level High, sedangkan Level yang dibutuhkan adalah High. Sehingga Hasil Penelitian menyatakan website Fik complaint UBL di karaktersitik Accessibility sesuai dengan standar ISO10002:2004.

3. Karateristik Responsiveness didalam penelitian menghasilkan level High, sedangkan Level yang dibutuhkan adalah High. Sehingga Hasil Penelitian menyatakan website Fik complaint UBLdi karaktersitik Responsiveness tidak sesuai dengan standar ISO10002:2004.

4. Karateristik Objectivity didalam penelitian menghasilkan level Medium, sedangkan Level yang dibutuhkan adalah Medium. Sehingga Hasil Penelitian menyatakan website Fik complaint UBLdi karaktersitik Objectivity sesuai dengan standar ISO10002:2004. 
5. Karateristik Charges didalam penelitian menghasilkan level High, sedangkan Level yang dibutuhkan adalah High. Sehingga Hasil Penelitian menyatakan website Fik complaint UBLdi karaktersitik Charges sesuai dengan standar ISO10002:2004.

6. Karateristik Confidentiality didalam penelitian menghasilkan level High, sedangkan Level yang dibutuhkan adalah High. Sehingga Hasil Penelitian menyatakan website Fik complaint UBLdi karaktersitik Confidentiality sesuai dengan standar ISO10002:2004.

7. Karateristik customer focused approach didalam penelitian menghasilkan level Medium, sedangkan Level yang dibutuhkan adalah Medium. Sehingga Hasil Penelitian menyatakan website Fik complaint UBLdi karaktersitik customer focused approach sesuai dengan standar ISO10002:2004.

\subsection{Saran}

Berdasarkan kesimpulan tersebut, peneliti memberikan saran sebagai berikut :

1. Penangan keluhan hendaknya dapat dijadikan acuan dalam memperkecil kesalahan pada saran atau prasarana yang ada di Fakultas Ilmu Komputer Universitas Bandar Lampung.

2. Fakultas Ilmu Komputer hendaknya mempertimbangkan sistem penanganan keluhan dengan para mahasiswanya dengan menggunakan situs handling complaint ini.

\section{DAFTAR PUSTAKA}

[1]Berger, Lance A., and Sikora, Martin J. 1994. The Change Management Handbook: A Road Map to Corporate Transformation, Richard Irwin, Inc.

[2]Davidoff, D.M. 1994. CONTACT: Customer Service in The Hospitality dan Tourism Industry. Prentice Hall, New York.

[3]Etzel, Michael J. Walker, Bruce J. Stanton, William J. 1997. Marketing. Edisi ke 11. USA. McGraw-Hill, Inc.

[4]ISO 10002 (2004), Quality Management: Customer Satisfaction - Guidelines for Complaints Handling, International Organisation for Standardisation, Geneva,.
[5]Lembaga Adminisrasi Negara Republik Indonesia, Strategi Peningkatan Kualitas Pelayanan Publik, Jakarta, LAN, 2006.

[6]Lembaga Adminisrasi Negara Republik Indonesia, Penyusunan Standar Operating Procedure, Jakarta, LAN, 2005

[7]Lembaga Administrasi Negara. 2003. Penyusunan Standar Pelayanan Publik. LAN. Jakarta.

[8]Marimin.1992.Pengenalan Sistem Pakar. Jakarta : Elex Media Komputindo. ( Sugiono, 2002:112 )

Utomo W., Gugum G., Heryono S., Ma'mun., Windra M., Mulyono A. 2005.

[9]Sugiarto, Endar. 1999. Psikologi Pelayanan Dalam Industri Jasa, Jakarta: PT Gramedia Pustaka: Jakarta

[10]Sutopo dan Suryanto, Adi. 2003. Pelayanan Prima. Jakarta: Lembaga Administrasi Negara Republik Indonesia.

[11]Tennie Chrisantiana 2007. Analisis Dan Perancangan Sistem Penanganan Keluhan Pelanggan Korporat, Surabaya:PT. Telkom Divre V Jawa Timur 